\title{
Tarihi Coğrafya Bakımından Önemli Bir Kaynak: Cihannüma
}

\author{
An important source for Historical Geography: Cihannüma
}

\author{
Mesut Elibüyük* \\ Ankara Üniversitesi, Dil ve Tarih-Coğrafya Fakültesi, Coğrafya Bölümü, Ankara
}

Öz: Bu yıl Kâtip Çelebi'nin doğumunun 400. yılıdır. Bu nedenle Unesco 2009 yılını Kâtip Çelebi yılı olarak kabul etmiştir. Bunun anısına burada, Kâtip Çelebi'nin Cihannüma adlı eseri coğrafya bakımından incelenip tanıtılmıştır. Kâtip Çelebi'nin hayatı ve eserleri hakkında birçok araştırma yapılmıştır. Araştırmaların çok az kısmı Kâtip Çelebi'nin coğrafya eserlerini ele almaktadır. Doğuda Hacı Halife, batıda ise Hacı Kalfa olarak tanınan Kâtip Çelebi, yaşamı içerisinde birçok eser yazmıştır. Bu eserlerin bir kısmı tarihi coğrafya bakımından oldukça önemlidir. Kâtip Çelebi doğu ve batıda yazılmış olan coğrafya eserlerini ve atlaslarını takip etmiştir. Bu eserlerden coğrafyanın ne kadar önemli olduğunu anlayan Kâtip Çelebi, gidilemeyen yerlerin coğrafya eserleri aracılığıyla ögrenilebileceğini belirtmektedir. Bunun sonucu olarak yazar iki tane Cihannüma adlı coğrafya eseri yazmıștır. Birincisi doğu düsünürlerinin görüslerine göre yazllmıștır. Ancak, birinci Cihannüma'nın batının coğrafya görüşlerine uymadığını gören Kâtip Çelebi 1650-1655 yılları arasında ikinciyi yazma gereğini duymuştur. Ayrıca Kâtip Çelebi coğrafyada kartografya konusunun ve harita yapmanın önemi üzerinde de durmuştur. Buna bağll olarak coğrafya kitaplarına harita koymanın gerektiğini de belirtmektedir. Bu sebeple Merkator Atlası'nı da çevirmiştir. Daha sonra İbrahim Müteferrika, Cihannüma'nın önemli bir coğrafya eseri olduğunu görünce 1732 yılında basmıştır. Ancak İbrahim Müteferrika, bastı̆̆ bu esere bazı eklemeler de yapmıştır. Böylece Kâtip Çelebi ve Cihannüma adlı eseri, kısa zamanda batıda ve doğuda tanınmıştır. Toplam 762 sayfa olan Cihannüma, Bölgesel Coğrafya özelliğinde yazılmış bir eserdir. Eser dünyanın kıtaları ve birçok ülkesi hakkında bilgi vermektedir. Bu esere 38 şekil konulmuş olup bunların 25 tanesi haritadır. Cihannüma denizlerden, karalardan, adalardan, akarsulardan, yerleşmelerden, yollardan ve ekonomik etkinliklerden de söz etmektedir. Kâtip Çelebi bütün bunları daha önce kullanılmayan coğrafya yöntemleriyle okuyucuya sunmuştur. Eser bütünüyle Tarihî Coğrafya bakımından önemli bir kaynaktır.

Anahtar Kelimeler: Cihannüma, Kâtip Çelebi, İbrahim Müteferrika, Coğrafya, Tarihi Coğrafya.

\begin{abstract}
Due to this year is the 400th birthday of Kâtip Çelebi, 2009 was accepted as the year of Kâtip Çelebi by Unesco. In the memory of this, the achievement of Kâtip Çelebi "Cihannüma" has been analysed and introduced at geographical point in this work. There are a lot of researches about Kâtip Çelebi and his life. A few of them are about his geographical achievements. Being known as "Hact Halife" in the East of the World and "Hacı Kalfa" in the West, Kâtip Çelebi wrote numerous achievements during his life. Some of them is considerably important for historical geography. Kâtip Çelebi examined the geographical achievements written in the East and the West. He understood from them how important geography is and indicated that the places, which can not be gone, can be learnt from geographical achievements. Then he wrote two books called as Cihannüma". He wrote the first book according to the opinions of the people who consider right. However this book didn't adapt the geographical views of the West. Therefore between 1650-1655 he wrote the second book. Besides, Kâtip Çelebi emphasised on the importance of the cartography and making map in geography. Accordingly, he specified the necessity of maps in the geography books. For this reason, he translated Mercator Atlas. In 1732 Ibrahim Müteferrika published "Cihannüma", when he saw the importance of this geographical achievement. He added some extra information to this achievement. At the end, Kâtip Çelebi and his achievement "Cihannüma" were known at short notice in the West and the East of the World. Being 762 pages, Cihannüma is an achievement of Regional Geography. It informs about the continents and many of countries of the Wold. There are 38 shapes in this achievement and 25 of them are maps. Seas, continents, islands, rivers, settlements, roads, economical activities are also mentioned in Cihannüma. Kâtip Çelebi offered all of thems by geographical methods, which were not used before. The achievement is completely important for historical geography.
\end{abstract}

Keywords: Cihannüma, Kâtip Çelebi, İbrahim Müteferrika, Geography, Historical Geography

*ỉletişim: M.Elibüyük, e-posta: elibuyuk@humanity.ankara.edu.tr 


\section{Giriş}

Bu yıl, Şubat 1609'da doğan Kâtip Çelebi'nin 400. doğum yılıdır (Gökyay, 1991: 3). Bu nedenle Unesco da bu yılı "Kâtip Çelebi Yılı" olarak kabul etmiştir. Konuyla ilgili olarak çeşitli çevreler tarafından birçok etkinlik yapılmıştır. Biz de burada Kâtip Çelebi'nin doğum yılı anısına, Cihannüma adlı coğrafya eserini inceleyip, eserin yazıldığı dönemde coğrafya alanına getirmiş olduğu yeni görüşler ve yenilikler ile Cihannüma'nın zamanında ve günümüzdeki önemine coğrafi yönden değineceğiz. Eser, birçok yönden önemli olmasına karşılık, döneminin en önemli coğrafya kitabıdır.

Coğrafya, Eskiçağ'dan beri bilinmekte olup adı, önemi ve özelliği hemen hiç değişmeden günümüze kadar sürüp gelmiştir. Dağılış, karşılaştırma ve nedensellik ilkeleri, fizikî, beşerî, ekonomik, bölgesel, tarihî ve matematiksel olmak üzere ana kümeleri ve her kümenin farkl1 yöntemlere sahip bilim dalları olan coğrafya, bugün fen bilimleri, doğa bilimleri ve sosyal bilimler gibi bir bilimler topluluğu oluşturmaktadır. Coğrafyacı, coğrafyanın ilkeleri ve yöntemleri doğrultusunda, geniş ve dar alanlarda araştırmalar yapar. Elde edilen coğrafî sonuçlardan birçok yönde olduğu gibi insanın yaşamını kolaylaştırma için yapılan planlamalarda da yararlanılır. Coğrafya, toplumların yaşamlarını kolaylaştırma yönünden, insanla doğal ortamın etkileşimini ve bu etkileşimin sonucunda ortaya çıkan olguların dağılışlarını karşılaştırarak nedenlerini sentez olarak ortaya koymaktadır. Bu bakımdan eskiden daha ziyade tasviri olan coğrafya, kendini yenileyerek geçmişten günümüze önemini hep korumuş ve korumaya da devam edecektir.

Osmanlı döneminde coğrafyadaki gelişme Kâtip Çelebi ile başlar (Türkay, 1999: 9). Kâtip Çelebi yaşadığı dönemde, coğrafyanın toplumların yaşamında bilgilenme bakımından ne kadar önemli olduğunu, Avrupa'da meydana gelen yeni coğrafî gelişmelere bağlı olarak yayınlanan eserleri inceleyince anlamış ve yazmış olduğu diğer eserlerinin yanında coğrafya eserlerine de yer vermiştir. Yazar, insanlara bulunduğu yerden ayrılmadan, dünya ve ülkeler hakkında yeni bilgi edinme olanağını coğrafya kitaplarının verdiğini ve bu nedenle de coğrafyanın ne kadar önemli olduğunu eserinde belirtmektedir. Doğaldır ki o dönemde yakın ve uzak sahalara veya ülkelere, güvenlik ve ulaşım ağının yetersizliği nedeniyle gitmek, oraları görmek ve gezmek kolay olmadığından, bu sahalara ait bilgilenme ancak coğrafya kitaplarından sağlanmaktaydı. Bu durum o dönemde coğrafyanın önemini açık olarak ortaya koymaktadır. Coğrafyanın önemini kavramış olan Kâtip Çelebi, XVII. yüzyıl ortalarında, yaklaşık 1650-1655 yılları arasında, genel hatlarıyla günümüzdeki "Bölgesel Coğrafya (Ülkeler Coğrafyası-Mevziî Coğrafya)" özelliğinde "Dünya Coğrafyası" olan "Cihannüma" adlı coğrafya eserini yazmıştır (Selen, 1991: 125; Akyol, 1940: 519). Eser, bölgesel coğrafya niteliğinde olup dünyanın birçok ülkesi ve Osmanlı Devleti yönetimindeki eyaletlerin fizikî coğrafyasının yanında özellikle beşeri coğrafyası, ekonomik coğrafyası, tarihî coğrafyası ve kültür coğrafyası konularını da içinde bulundurmaktadır.

Kâtip Çelebi, coğrafya konularıyla ilgili olarak Cihannüma'dan başka Şeyh Mehmed İhlâsî Efendi ile birlikte Gerhard Merkator'un “Atlas Minor” adlı eserinin Latince'den çevirisini de yapmıştır. Döneminde coğrafya ve coğrafyacılar için önemli olan bu eserde, Kuzey Kutbu ve Avrupa ülkelerinin coğrafyası anlatılmaktadır. Kâtip Çelebi, bu atlastan Cihannüma'nın yazımı sırasında çok yararlanmıştır. Yazarın coğrafya ile ilgili bir diğer eseri de Kitâb-1 Müntehab-1 Bahriyye adını taşımaktadır. Bu eser, Evliya Çelebi'nin Kitâb-1 Bahriye adlı eserini esas almıştır. Cihannüma'nın yazımında yararlanılmış olan eser, genel olarak denizler ve kıyılar hakkında bilgiler vermektedir (Gökyay, 1982: 73).

Türkiye'deki kütüphanelerde olduğu gibi Avrupa'nın ileri gelen birçok kütüphanesinde Cihannüma'nın el yazma nüshalarının var olması, eserin o dönemde olduğu gibi günümüzdeki önemini de ortaya koymaktadır. Cihannüma, Kâtip Çelebi tarafından yazılmış olmasına karşın, İbrahim Müteferrika tarafindan bazı metin, şekil ve harita ekleri yapılarak 1732 yılında basılmıştır (Selen, 1991: 121). Bu eser, son zamanlara kadar birçok ülkede ve özellikle de doğu ülkelerinde kullanılmış, coğrafya ve tarihî coğrafya alanında ise temel başvuru kitaplarından biri olmuştur. 
Eserin kendisi tarihî bir belge olduğundan ve geçmişin coğrafyası olan tarihî coğrafya araştırmaları da bu tür tarihî eserler ve belgelerden yararlanılarak yapıldı̆̆ından Cihannüma, günümüzde tarihî coğrafya alanında çalışma yapacaklara da oldukça değerli bilgileri sunan, bilimselliği kanıtlanmış önemli bir kaynak eserdir. Zaten, Kâtip Çelebi de eserin ilk sayfalarında, bu kitabın benzerinin bundan önce yazılmadığını, ilk defa kendisinin yazdığını belirtmektedir. Ancak, ülkemizde tarihi coğrafyaya gerektiği kadar değer verilmediğinden, coğrafyacılarımızın bu eserden gereği gibi yararlandıklarını söylemek mümkün değildir. Çünkü "Tarihî Coğrafya", gelişmiş ülkelerde oldukça önemli bir yere sahip olup, oradaki üniversitelerin ilgili fakültelerinde bölüm veya anabilim olarak yer almış, buna karşılık ülkemizde ise bazı üniversitede sadece bir ders olarak kalmıştır.

Coğrafya, özellikle tarihî coğrafya bakımından, bilim alanındaki önemini her zaman korumuş bulunan Cihannüma, birçok ülkenin ve bilhassa Osmanlı Devleti'nin yönetimi altındaki sahaların, yalnız genel coğrafya ve tarihsel bilgilerini değil, aynı zamanında o dönemin beşerî ve ekonomik coğrafyası hakkında da oldukça ayrıntılı bilgiler vermektedir. Ancak eserin, Kâtip Çelebi tarafindan yazılmış tam bir nüshası da bu güne kadar bulunamamıştır. Bu da Cihannüma'nın, yazarı tarafından tamamlanamadığını göstermektedir. Buna rağmen eser, yazıldığı zaman ve daha sonra, özellikle de basımından itibaren, yalnız Osmanlı ülkesinde değil, öncelikle Avrupa'da olmak üzere dönemin birçok ülkesinde de büyük ilgi görmüştür.

Yukarıda da belirtildiği gibi Cihannüma'nın birçok kütüphanede nüshalarının bulunduğu bilinmektedir. Ancak, yaygın olarak bilinen, İbrahim Müteferrika tarafından şekil, harita ve metin ekleri yapılarak basılmış olan Cihannüma'dır. Bu durum, eseri incelemek isteyenler için bazı soru ve sorunları da beraberinde getirmektedir. Bunlar, genel olarak eserin Kâtip Çelebi tarafindan yazılan kısmının neresi olduğu, kimlerin ne kadar eklediği, eklenenlerin ne olduğudur. Söz konusu sorular ve sorunlar üzerinde konunun uzmanları tarafından birçok araştırma yapılmış ve yapılacaktır.

Kâtip Çelebi Cihannüma adlı eserinde, yaşadığı dönemde doğu ve batıda coğrafya alanında var olan yaklaşımları birbiri ile bağdaştırarak yepyeni görüşlere yer vermiştir. Bu yönüyle eser, Osmanlı coğrafya anlayışına yeni ve bilimsel bir görüş getirmiştir. Ayrıca doğunun, özellikle de Eskiçağ'ın yüce medeniyetlerine ait çoğu önemini ve gerçekliğini yitirmiş birçok görüşünü bir tarafa bırakan Kâtip Çelebi, özellikle Avrupa ülkelerinde, coğrafya alanında ortaya çıkan ve kullanılan yeni görüş ve gelişmeleri esas alarak Cihannüma'yı meydana getirmiştir. Dünya Coğrafyası özelliğinde olan bu eserin, yalnız metin olarak meydana getirilmesinin yeterli olmadığını dikkate alan yazar, metnin arasına Avrupa'daki örneklerinde olduğu gibi hazırladığı şekilleri ve haritaları da koymuştur. $\mathrm{Bu}$ şekil ve haritalar çok renkli olup üzerinde bazı açıklamaları da bulundurmaktadır.

Basımından sonra yurt içinde ve dışında daha yaygın olarak tanınan ve kullanılmaya başlanan Cihannüma, Avrupa'da birçok dile çevrilmiştir. Bu sayede eser, geniş okuyucu kitlesine ulaşmıştır (Gökyay, 1991: 61). Kâtip Çelebi'nin bu eseri, döneminde olduğu gibi günümüze kadar da coğrafya alanında birçok kişi tarafından yazılan eserlerin ortaya çıkmasına temel kaynak olmuştur (Taeschner, 1924; Pitcher, 1972). Ayrıca, birçok konuda coğrafî bilgilere sahip olan Cihannüma, XIX. yüzyılda Anadolu'yu gezen Avrupalı seyyahlar tarafından da önemli ve vazgeçilmez bir bilgi kaynağı ve yol kılavuzu olarak kullanılmıştır.

\section{Tanıtma ve Değerlendirme}

Burada tanıtılan Cihannüma'nın ilk sayfasındaki mühür ve altındaki bilgilerden, Millet Genel Kütüphanesi H. Alipaşa kısmında 736 numarada kayıtlı olduğu anlaşılmaktadır. Bu sayfadan sonra gelen dört sayfaya numara verilmemiştir. Bu kısım önsöz özelliğinde olup, Kâtip Çelebi burada, Cihannüma adlı eseri yazma sebebi hakkında bilgi vermektedir (Şekil 1). Bunun devamında yer alan ve yine numarasız olan 22 sayfada, "Fihris" adı altında eserin içindekileri yer almaktadır (Şekil 2). Fihristten sonraki sayfalar eserin asıl metin kısmını oluşturmaktadır. Buradan itibaren sayfalar bir numaradan başlayarak 698'e kadar numaralanmıştır. Sayfalardaki yazılar ise yaldızlı bir çerçeve içinde sunulmuştur. Buradaki ilk sayfada eserin ve yazarın adı, bir sanat eseri niteliğindeki, renkli süslemelerin arasında verilmiştir (Şekil 3). 


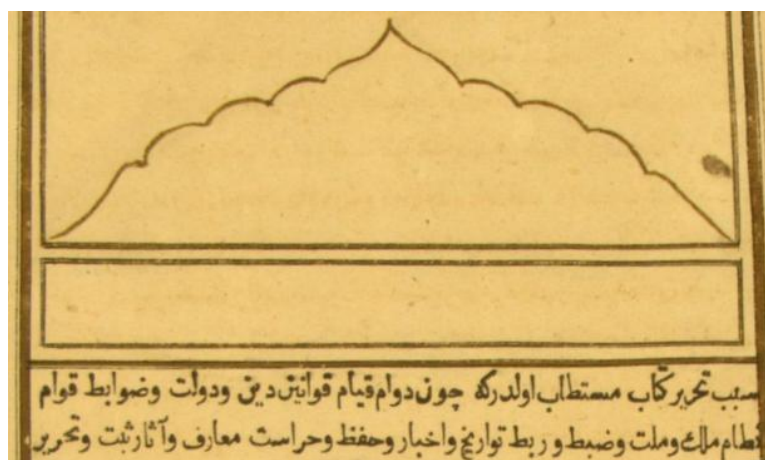

Şekil 1. Cihannüma'nın ilk sayfanın başı (Sebeb-i tahrir-i kitab-1 müstetab oldur ki ...)

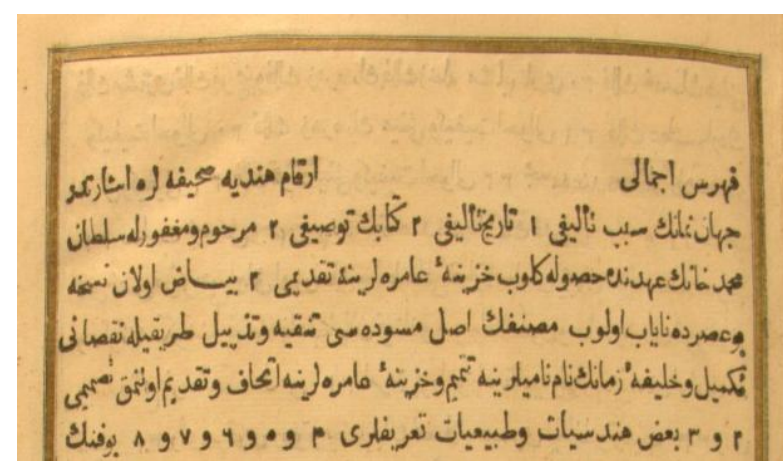

Şekil 2. Fihristin (İçindekiler) baş kısmı. (Fihris icmali ...)

Esere, içinde yer verilen coğrafî konular ile anlatılan yerlere ait bilgilerin kolaylıkla anlaşılabilmesini sağlamak amacıyla, tamamı renkli olmak üzere, titizlikle hazırlanmış 38 adet şekil, çizelge ve harita, sayfa numarası verilmeden eklenmiştir. Bunlardan 11 tanesi matematik coğrafya konularıyla ilgili şekil, ikisi çizelge ve 25 tanesi de eserde yer alan sahalara ait haritadır. Bazı şekillerin arka kısmı boş olup, numara verilmemiş sayfa durumundadır. Bunlarla birlikte eser, toplam 800 sayfa olarak düzenlenmiştir.

Kâtip Çelebi eserinde, çeşitli sebeplere bağlı olarak birçok ülkeye yaptığı seyahatlerde gördüğü yeni yerler, yerleşmeler ve insanlar ilgisini çekince, görmediği yerleri de görüp öğrenme isteğinin artı̆̆ını söylemektedir. Kâtip Çelebi'nin bu öğrenme isteği, özellikle batı ülkelerinde, dönemine göre daha bilimsel ve yeni görüşlere uygun olarak yazılmış coğrafya eserlerini inceledikçe daha da artmıştır. Coğrafyanın, ülkeleri öğrenme bakımından ne kadar önemli olduğunu bu sayede anlayan yazar bunu eserinde özellikle vurgulamaktadır. Bunun üzerine Kâtip Çelebi, ilk iş olarak doğunun, İlkçağ'dan dönemine kadar yazılmış olan coğrafya konularıla ilgili eserleri ile batıda yazılmış olan dönemine ait coğrafya kitapları ve atlaslarını temin ettiğini ve bunları okuyup incelediğini de kitabın giriş kısmında belirtmektedir.

Coğrafya konularını içinde bulunduran Türkçe, Arapça ve Farsça eserleri temin edip okuyan Kâtip Çelebi, bu eserlerde ülkelere ait bilgilerin çoğunun anlaşılmaz ve yanlış olduğunu görmüş, bu sebeple Cihannüma adında yeni bir eser yazmaya karar vermiştir (Gökyay, 1991: 61). Daha ziyade doğu ve eski kaynaklara bağlı kalarak kaleme aldığı ilk Cihannüma’yı, bilgi kaynaklarındaki bilgiler ile görüşlerin, batıdaki yeni görüş ve bilgilere göre eskiliği, yetersizliği ve farklılığı nedeniyle tamamlamamış yarıda bırakmıştır. Batıda coğrafya alanında meydana gelen yeni gelişmelerin 1şığı altında yazılmış olan coğrafya eserleri ve bilhassa Merkator Atlası (Atlas Minör), Kâtip Çelebi'nin ikinci Cihannüma'yı yazmasına kaynak olarak yardımcı olmuştur. Ancak, bu ikinci eser de tamamlanmamıştır.

İkinci eserin yazım planı ve içindeki bilgilerin, birinciden farklı olarak düzenlendiği söz konusu eserler karşılaştırıldığında anlaşılmaktadır. Kâtip Çelebi'nin yeniden çağdaş bilgilere dayalı olarak yazmış olduğu bu ikinci Cihannüma'nın önemini anlayan İbrahim Müteferrika da 1732 yılında esere bazı metin, şekil ve harita ekleyerek yayımlamıştır (Selen, 1991: 121). Günümüzde yerli ve yabancı coğrafya, tarihî coğrafya, tarih ve diğer alanlarda araştırma yapanların çoğunlukla yararlandığı Cihannüma işte budur.

Bu Cihannüma'nın baş kısmında, yukarıda da belirtildiği gibi kitabın yazılma sebebi, adı ve önemi hakkında bilgiler bulunmaktadır. Bu sayfalardan sonra "Fihris" yani içindekiler verilmiştir. 
Devamında ise başta renkli süslemenin içinde kitabın adı ve yazarının bulunduğu asıl metin kısmına geçilmiştir (Şekil 3). Bu kısımda önce, Cihannüma'nın yazımı için kaynak olan eserler tanıtılmış, takiben coğrafyanın tanımı ve sınıflandırılması yapıldıktan sonra, amacı ve faydası açıklanmıştır (Sayfa 15-17). Kâtip Çelebi, Cihannüma'nın yazımı sırasında "İslamîyye ve Latinîyye" coğrafya eserleri ile "Frengî Atlasları" ve Gerhard Merkator'un "Atlas Minör" gibi eserlerini incelemiş, hatta bir Fransız mühtedisi (sonradan İslamiyeti kabul eden) olan Şeyh Mehmet Îhlâsî ile beraber bu atlasın tercümesini yaparak bunlardan yararlanmıştır. Yazar, sözü edilen coğrafya kitapları ve atlaslardan nasıl yararlanıldığı da burada anlatmaktadır.

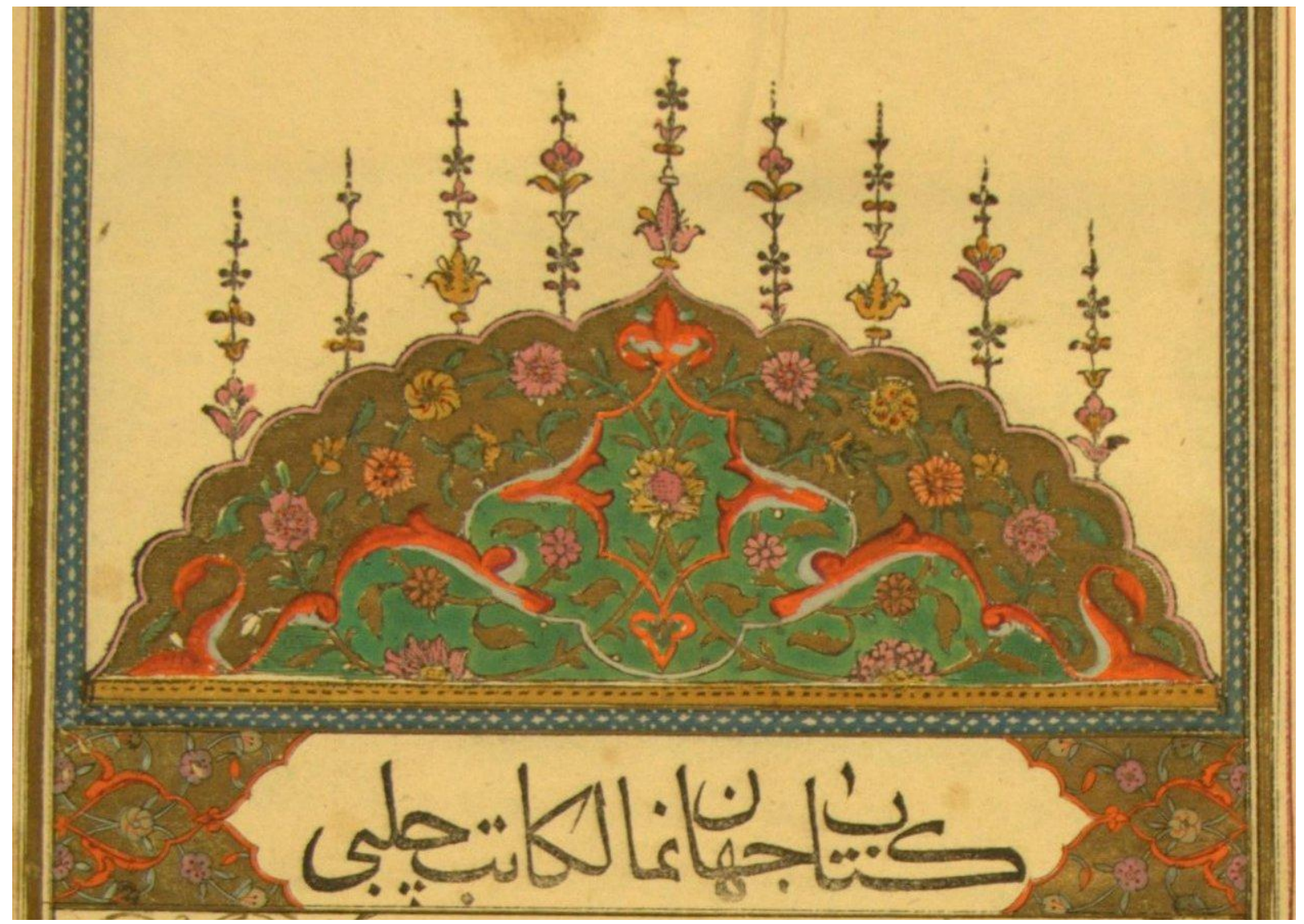

Şekil 3. Eserin fihristten sonra sayfa numarası verilerek asıl metin kısmına geçilen sayfasının başına, kitabın adı ve yazarı “Kitab-1 Cihannüma Katib Çelebi” süslemeli olarak bu şeklinde konulmuştur (Cihannüma s.1).

$\mathrm{Bu}$ açıklamaları matematiksel coğrafya ile kartografya konuları takip etmektedir. Matematiksel coğrafya konuları batıdaki yeni görüşler doğrultusunda ele alınmaktadır (Cihannüma s. 8-13). Konular "Arzın Küre Oluşu, Felekler ve Unsurlar, Kutuplar ve Daireler, Medarlar ve Mıntakalar, Hakikî İklimler, Tul ve Arz Daireleri, Mevki Tayini, Mesafe Ölçüleri ve Mikyaslar, Cihetler ve Rüzgârlar, Kara ve Deniz Haritaları, Kara Haritalarının Yapılmasındaki Güçlükler” olarak ele alınıp işleniyor. Metin içinde 7. ve 8. sayfalar ile 19. ve 20. Sayfalar arasına matematiksel coğrafya ile ilgi şekiller konulmuş ki bu şekiller arasında güneş ve ay tutulması konularında çizimler de bulunmaktadır (Şekil 4). Bu arada, coğrafyanın önemi ve sınıflandırılması, fenle ilgisi ve amacı da burada belirtilmektedir (Cihannüma s. 15-16). 

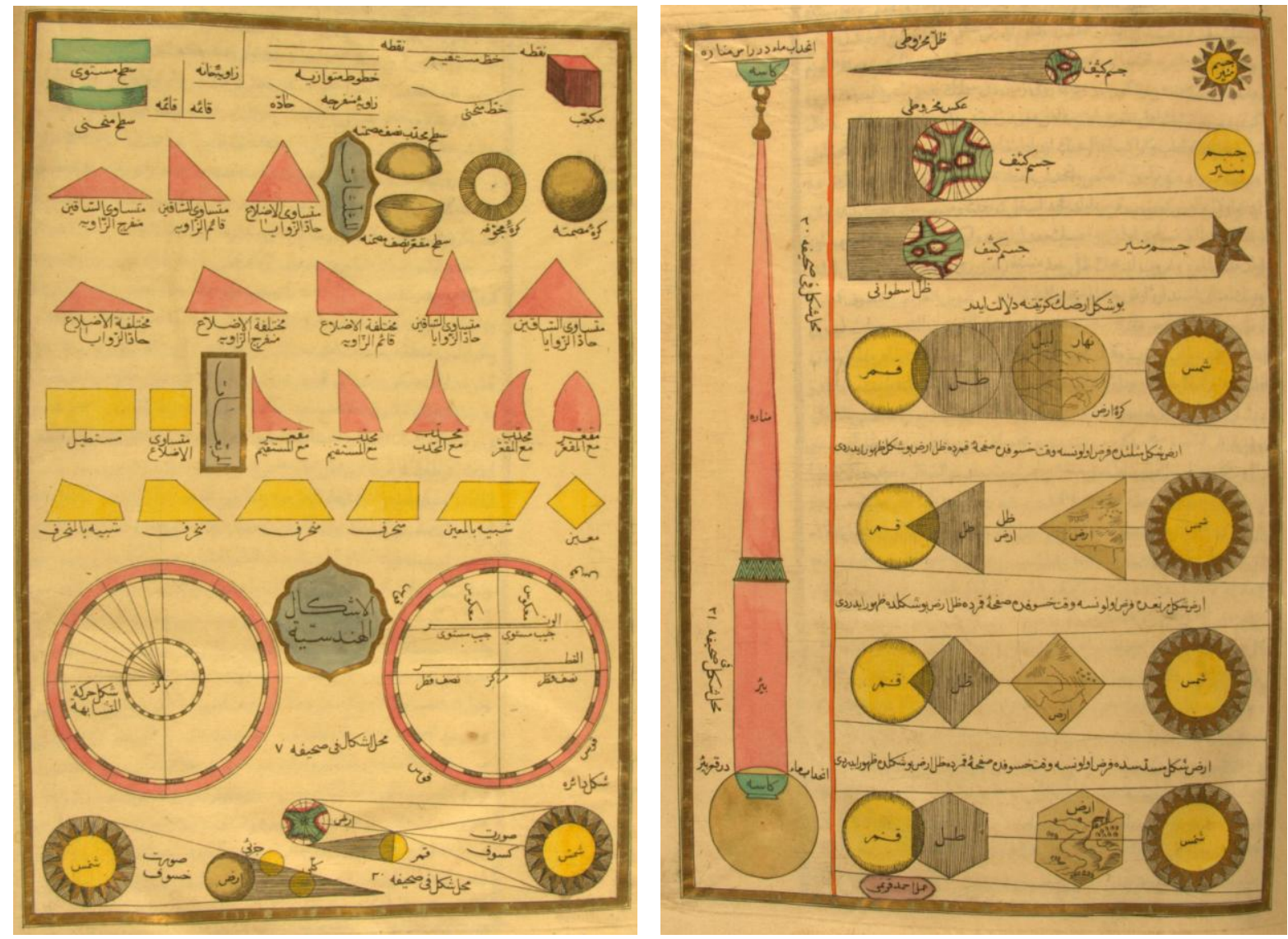

Şekil 4. Soldaki şeklin üst kısmında bazı geometrik şekiller (bunlarla ilgili bilgiler Cihannüma'nın 7. sayfasında verilmiştir) ile alt kısımda Güneş ve Ay tutulmalarını gösteren şekiller konulmuştur (bunlarla ilgili bilgiler Cihannüma'nın 20. sayfasında verilmiştir). Sağdaki şekilde Güneş tutulması gösterilmektedir (bunlarla ilgili bilgiler Cihannüma'nın 20-21. sayfalarında verilmiştir). Ayrıca şekilleri yapanın adı, sağdaki şeklin alt kısmında “Ahmed Kırımî” olarak yazılmıştır.

Cihannüma'nın 21-22. sayfalarında burçlar ve gezegenler konularıla ilgili bir şekil konulmuştur (Şekil 5). Burada Gezegenler, Ay ve Güneş Dünya'ya uzaklıklarına göre sıralanmışlardır. Bu şeklin üzerinde 12 burç bulunmaktadır. Bunlar "Cedi, Delu, Hut, Haml, Nur, Coza, Seretan, Ised, Semboli, Mizan, Akreb, Kos" olarak verilmiştir. Gezegenler "Utarit (Merkür), Zöhre (Venüs), Merih (Mars), Müşteri (Jüpiter), Zühal (Satürn)" adlarıyla kaydedilmiştir. Şeklin solunda ise yine burçlar verilmiş buna ek olarak çevre 10 derecelik parçalara ayrılmış, kutup daireleri, dönenceler ve başlangıç meridyeni temsilen konulmuştur.

Kitabın 27-28. sayfaları arasında bulunan ve çok renkli olarak hazırlanmış olan şekil ise yarım küreleri birer daire ile gösteren Dünya'yı ifade etmektedir. Bu daireler kuzey ve güney yarım küreler olup buralarda yaşayan canlılar resimlerle gösterilmiş ve yanlarına da kısa açıklamalar yapılmıştır. Bu şekli yapanın ismi "Mıgırdıc Galata" olarak yazılmıştır (Şekil 6).

Matematiksel coğrafya ile ilgili olan başka şekiller de esere eklenmiştir. Bunlardan eserin 47.48. sayfaları arasında gök cisimlerinin hareketleri ve mevsimlerle ilgili olanlar da bulunmaktadır (Şekil 7). Cihannüma'da bazı çizelgeler de kullanılmıştır. Sayfa 51-52 arasında "Cedvel-i Ekalim" başlığıyla bir çizelge ve yanında da bir şekil bulunmaktadır. Çizelgede "iklim sayısı", "daire sayısı", iklimlerin saat ve dakika, derece ve dakika olarak konumları yazılmışıtır. Bilgiler 24 satır ve 8 sütun olarak verilmiştir. Kolonların kolay takip edilebilmesi için her biri farklı olarak renklendirilmiştir. $\mathrm{Bu}$ çizelgeyi yapanın adı Ahmed Kırımi olup sağ alt köşeye süslü bir çerçeve içinde yazılmıştır (Şekil 8). 


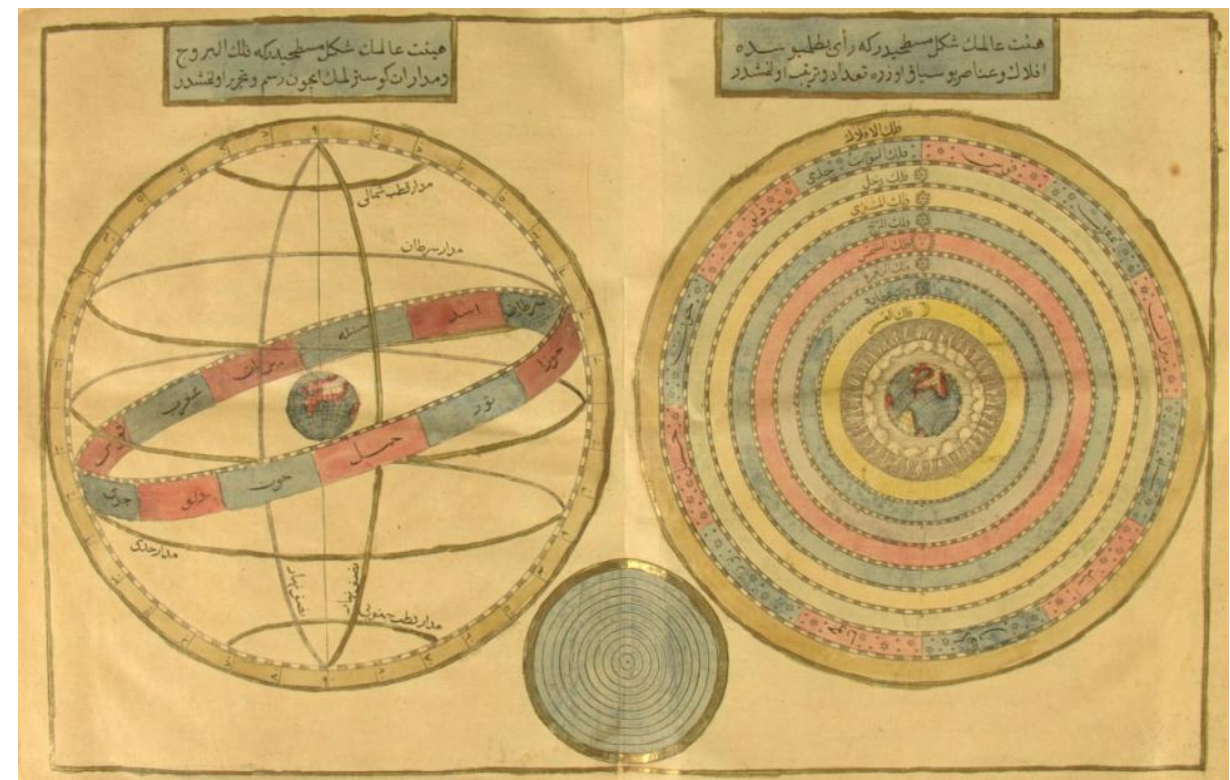

Şekil 5. Burçlar ve gezegenleri gösteren şekil

Yönlerle ilgili olarak bir çerçevenin içine beş ayrı şekil konulmuştur. Birer sanat eseri niteliğinde olan bu şekillerle ilgili açıklama bilgilerinin Cihannüma'nın 60. sayfasında olduğu, yine bu şekil sayfasının sol üst köşesinde yazılmıştır. Çok renkli olarak hazırlanan bu şekilleri Mıgırdıc Galata'nın yaptığı bu sayfanın altında kayıtlıdır (Şekil 9).

Memleketler ve şehir adları üzerinde de duran Kâtip Çelebi, batıda coğrafya alanında gelişen yeni görüşlerden de söz etmektedir. Kartografya ve özellikle de dönemindeki coğrafya konuları ve ülkeler bakımından, harita ve haritacılık hakkındaki düşüncelerini açıklıkla ortaya koyan Kâtip Çelebi, haritaların ne kadar önemli olduğunu ve yazılan coğrafya eserlerinin içine, konular ve bilgileri verilen alanlarla ilgili şekil, çizelge ve haritaların konulması gerektiğini de özellikle belirtmektedir.

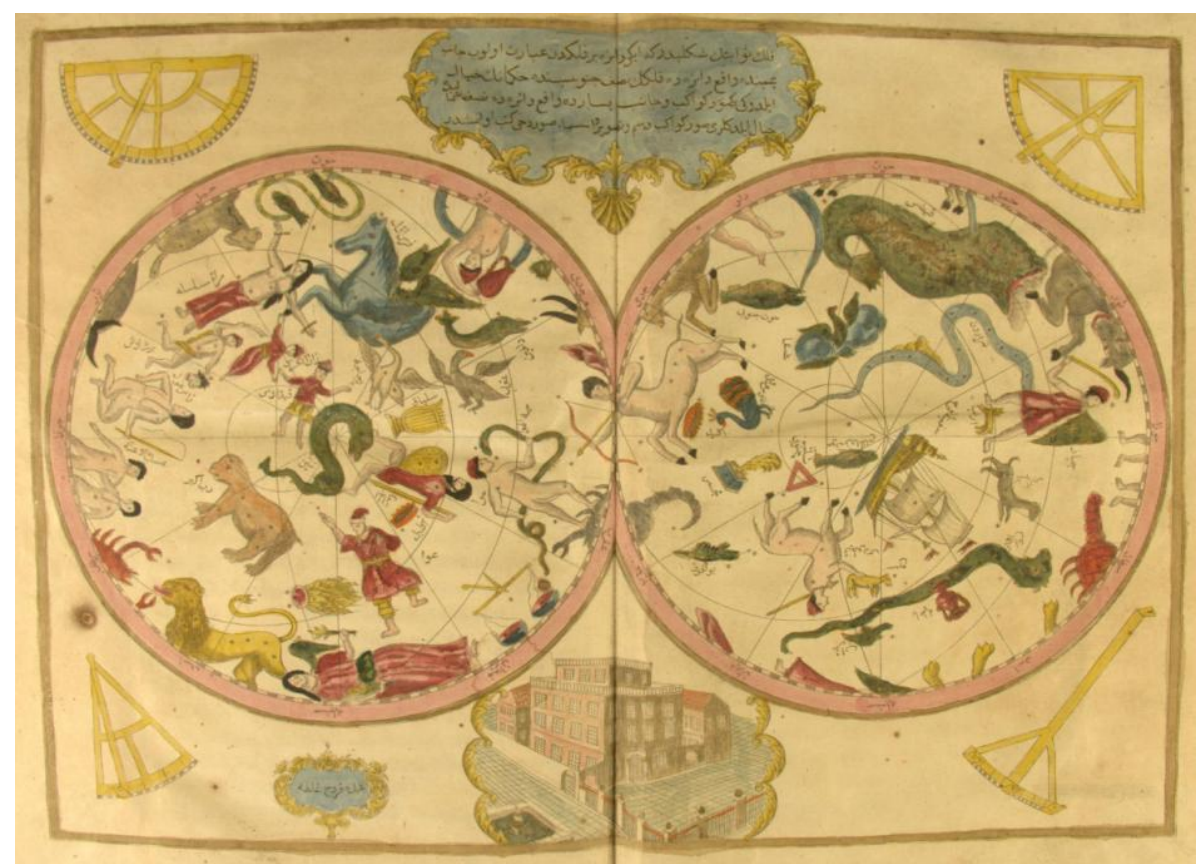

Şekil 6. Kuzey ve güney yarımküreleri gösteren şekil (Sayfa 27-28) 


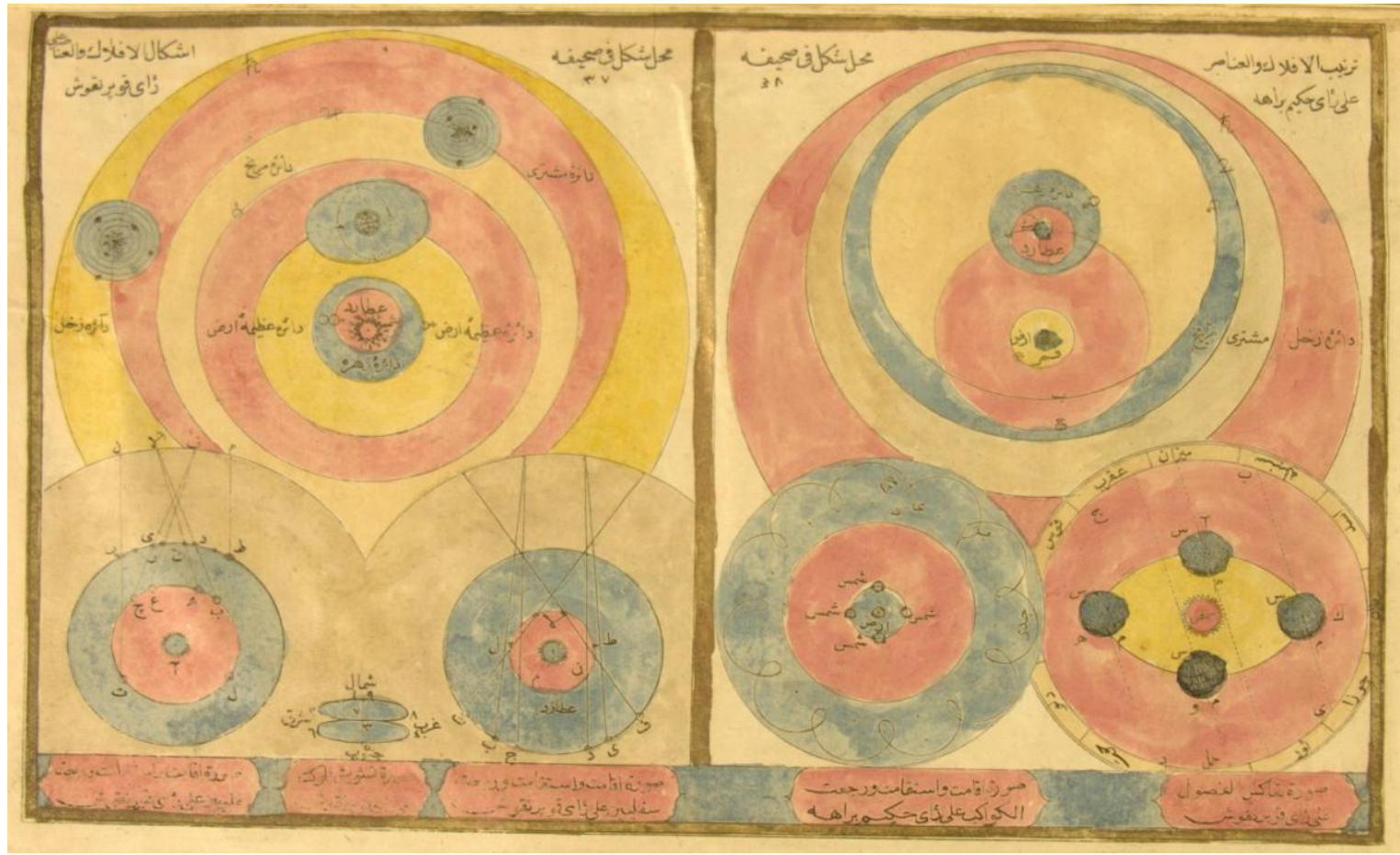

Şekil 7. Dünya ve gök cisimlerinin hareketi ve mevsimlerle ilgili şekil (Sayfa 47-48)

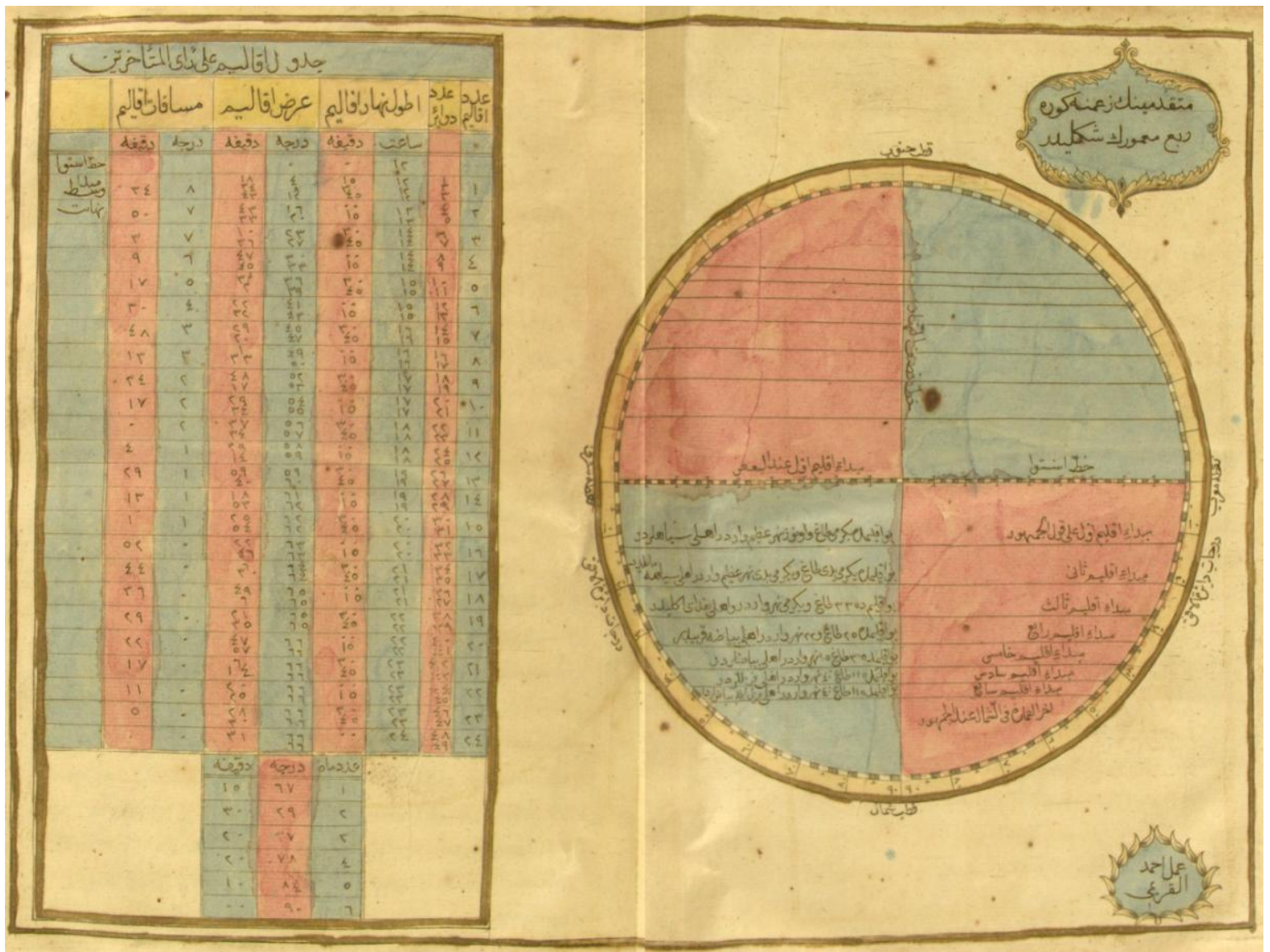

Şekil 8. İklimleri saat-dakika, derece-dakika olarak gösteren çizelge (Sayfa 51-52) 


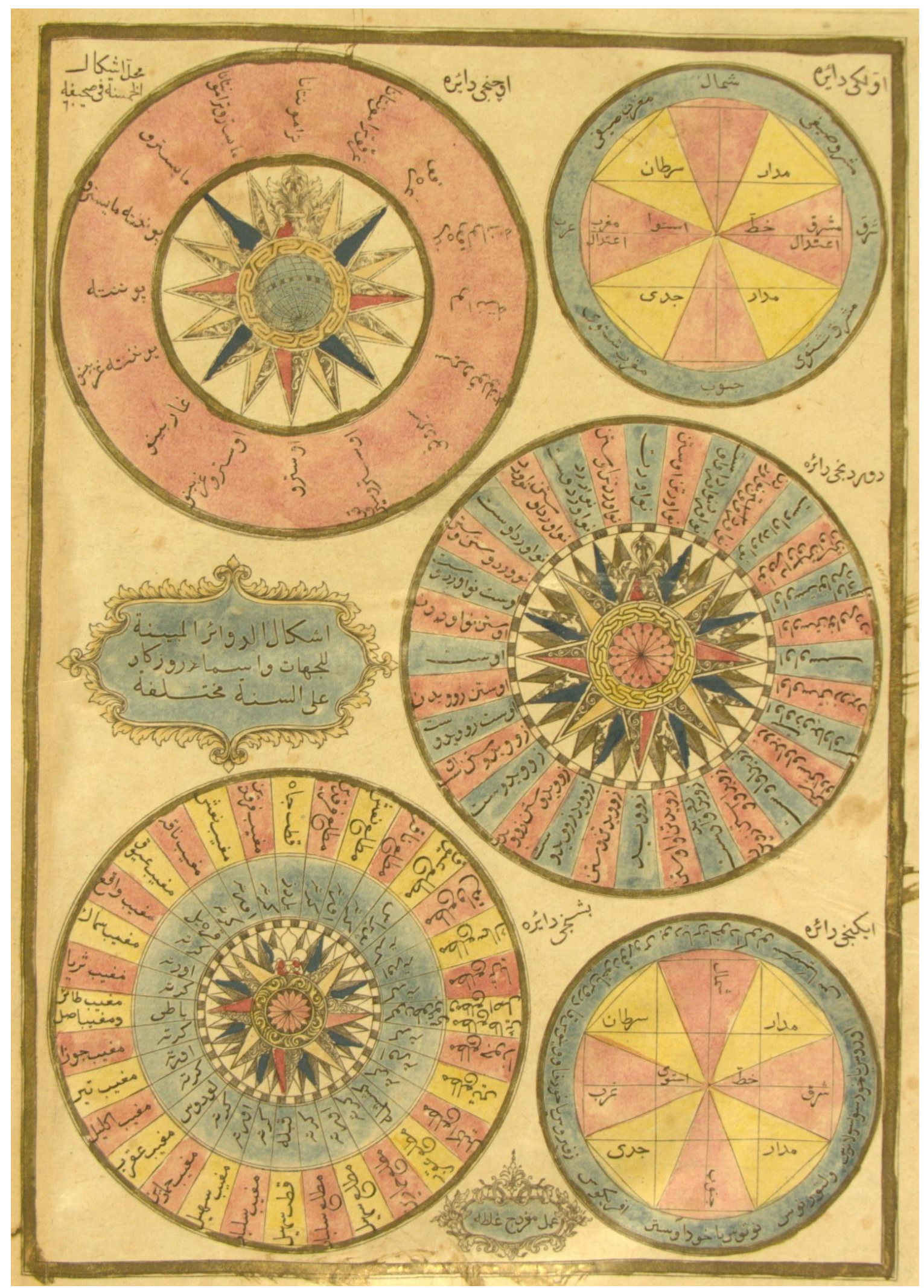

Şekil 9. Rüzgârgülleri ve yönlerle ilgili şekiller. Bunlar beș adet daire şeklinde olup, yapanı şeklin altında "Mıgırdıç Galata" olarak yazılmıştır (Sayfa 59-60). 
Kâtip Çelebi, bu bilgilerden sonra kendisinin de belirttiği esas coğrafya konularına geçerek yeryüzü, denizler, karalar ve yer küresi ile ilgili genel bilgiler vermektedir. Genel bilgilerin verildiği bu kısmın ilk konusu denizlere aittir. Denizlerle ilgili konular "Denizlerin Oluşu ve Derinlik, Denizlerin Taksimi, Deniz Hareketleri, Akıntılar, Med ve Cezir, Med ve Cezirin Faydası, Kıyılar ve Denizler, Fırtınalar, Tayfunlar, Denizlerde Tuzluluk, Deniz Seferleri, Mevsimler" başlıkları altında açıklanmaktadır. Kâtip Çelebi kitabında denizlerden sonra ikinci sırada karalara yer vermiştir. Önce Dünya hakkında genel bilgiler verilmiş ve takiben karalara geçilmiştir (Şekil 10). Ele alınan karalar ise "Karaların Taksimi, Avrupa, Afrika, Asya, Amerika, (Şekil 11), Şimal Kutbu, Cenup Kutbu (Şekil 12)" olarak sıralanmakta ve bunlar hakkında toplu olarak bilgiler verilmektedir. Yazar daha önce sözü edilmeyen kıta kavramına burada değinmekte ve ilk olarak kıtalardan söz ederek Eskidünya (Asya, Avrupa, Afrika), Yenidünya (Amerika) kıtalarını anlatmaktadır. Ayrıca, Kâtip Çelebi eserinde bilgisini verdiği kıtaların çok renkli haritalarını da koymuştur. Bu haritalar da eserde yenilik olarak görülmektedir.

$\mathrm{Bu}$ konularla ilgili olarak genel bilgiler verildikten sonra, ülkeler hakkındaki açıklamalara Asya'nın doğusundaki adalardan başlanmaktadır. Bu adalar "Yaponya, Yeni Gine, Moluk, Mindenao, Cava, Sumatra, Borneo, Seylan, Çin ve Hint Adaları" şekilde sıralanmıştır (Şekil 13). Bu adalara ait genel bilgiler çoğunlukla tasvir şeklinde verildikten sonra Asya kıtasındaki ülkelere geçilmektedir.


Şekil 10. Dünya Doğu Yarımküre ve Batı Yarımküre olarak verilmiş ve kıtalar belirtilmiştir

Asya kıtasına "Çin-i Maçin ve Hitay" gibi uzak doğu ülkelerinden başlanmakta ve buradan batıya doğru diğer ülkelerden bahsedilmektedir. Bunlar Hind, Sind (Batı Pakistan), Kaşmir, Tibet, Zabulistan (Afganistan), Badahşan, Toharistan” ülkeleridir. Asya'nın güneyindeki bu ülkelerden sonra İran, Türkistan ve Orta Asya ülkelerine ait bilgiler verilmektedir. Sözü edilen sahadaki ülkeler "Sicistan, Sistan, Kirman, Hürmüz, Lâr, Fars, Huzistan, Loristan, Cibal, Irak-1 Acem, Horasan, Kuhistan, Tabaristan, Mazenderan, Deylem, Ceylan, Harizm, Maveraünnehr, Doğu Türkistan” olarak sırayla anlatılmaktadır. Bu ülkelere ait bilgiler verildikten sonra, Asya'nın batısındaki sahalara geçilmektedir. Burada önce "Azerbaycan, Arran, Mogan, Şirvan, Dağıstan, Gürcistan” ülkeleri ele alınmakta ve takiben Doğu Anadolu ile Arabistan Yarımadası üzerinde yer alan Osmanlı eyaletleri hakkında bilgiler verilmektedir. Bu sahalara ait bilgiler "El Cezire, Irak, Arap Yarımadası, Şam, Halep" olarak başlamakta ve devamında Anadolu topraklarına geçilmektedir. Burada "Adana, Maraş, İçel, Sivas, Karaman, Anadolu" eyaletleri sırayla anlatılarak boğazlara kadar gelinmektedir. Katip Çelebi kedisinin gezip gördüğü ve bilgilerini bizzat kendisinin derleyerek değerlendirdiği yerleri daha ayrıntılı olarak anlatmaktadır. 

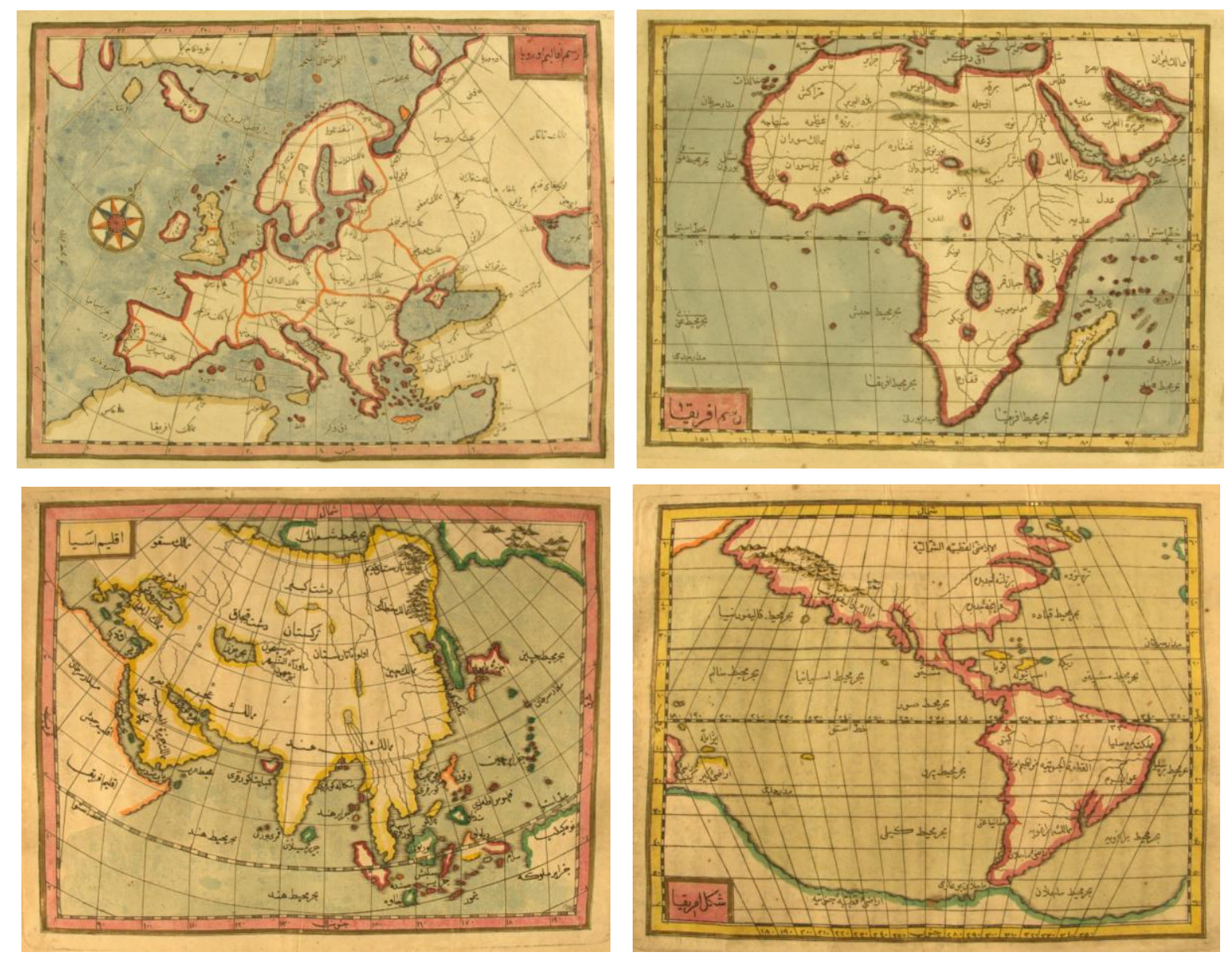

Şekil 11. Cihannüma'da verilmiş olan kıtalar (Avrupa s.99-100, Afrika s.101-102, Asya s.103-104, Amerika s.113-114)

Anadolu'daki eyaletlere ait bilgiler verilirken bazı konularda dönemiyle ilgili olarak oldukça ayrıntıya inilmektedir. Burada şehir ve kasabalardan, kalelerden bunların konumlarından ve bulundukları yerin coğrafi özelliklerinden ayrı ayrı söz edilmektedir. Bir yerin coğrafi olarak, diğer bir yere göre konumu yönlere bağlı kalınarak açıklanmaktadır. Şehir ve kasaba özelliğindeki yerleşmeler ile burada yer alan kaleler arasındaki mesafeler menzillerle belirtilmektedir. Şehir ve kasabalarda bulunan cami, hamam ve çarşıların sayıları ile bunlar hakkında bazı bilgiler de verilmektedir. Ayrıca, fiziki coğrafya bakımından anlatılan sahadaki dağ, ova, nehir ve göller hakkında da yer yer açıklamalar yapılmaktadır. Beşeri coğrafya konularından yerleşmeler ile bunların bulundukları sahanın ekonomik faaliyetleri ve önemli olan çeşitli ürünleri de belirtilmektedir.

Eserin 7-66. sayfaları arasına, matematik coğrafya ile ilgili olarak dünya, dünyanın hareketleri, mevsimler, enlem ve boylam daireleri konularında şekiller konulmuştur. Bundan sonra gelen 71 ile 672. sayfalar arasına, anlatılan alanlarla ilgili olmak üzere haritalar yerleştirilmiştir. Bunlar "Dünya Şekil 10), Akdeniz, Ege Denizi ve Adalar (Şekil 14), Venedik Körfezi, kıtaları gösteren Avrupa, Afrika, Asya, Kuzey ve Güney Amerika (Şekil 11), Kutuplar (Şekil 12), Japonya, Hind ve Çin Adaları (Şekil 13), Sumatra, Filipin, Borneo" ve "Çin, Hindistan, İran, Afganistan, Pakistan, Maveraünnehr, Tebriz (Urmiye) Gölü (Şekil 15), Kafkasya (Şekil 16), Arabistan Yarımadası haritalarıdır. Ayrıca, Anadolu (Şekil 17) ve İstanbul Boğazı (Şekil 18)" haritaları değişik tarzlarda yapılarak konularla ilgili yerlere konulmuştur. Bu haritaların bulundukları sayfalara numara verilmemiştir. Bu şekil, çizelge ve haritaların bazısında nereye ait olduğunu belirten başlık varken, bazısında ise hangi sayfadaki bilgilere 
ait olduğunu gösteren notlar bulunmaktadır. Haritaların bir kısmında "Fersah, Mil, Mesafe, Saat" olmak üzere dört tür çizgi ölçeği ile yönleri gösteren rüzgârgülü konulmuştur. Ayrıca, bazı haritalarda ise yönler, kitabeler kısmına yazılmıştır. Haritaların üzerinde yerleşme birimleri çoğunlukla o dönemin şehirlerini ifade eden şekillerle gösterilmiş, önemli akarsular çizilmiş ve yer adları da yazılmıştır.

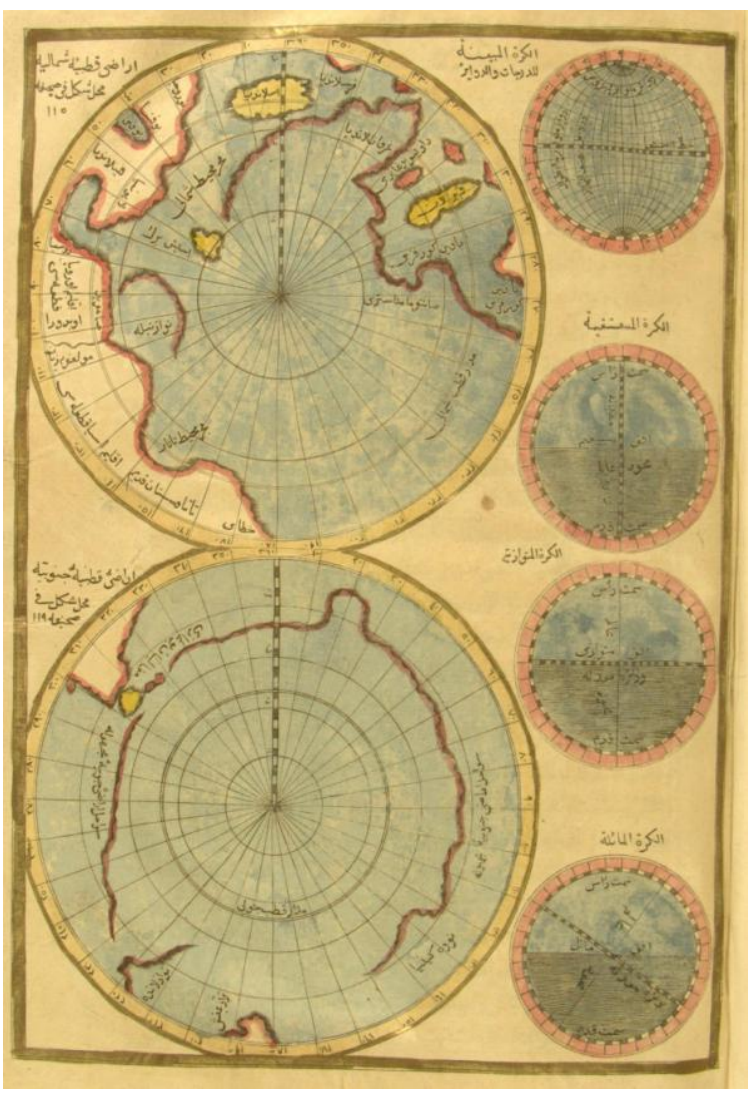

Şekil 12. Kuzey ve Güney Kutup çevreleri (s.119-120). Bunlarla ilgili açılamalar 115 ve 119. Sayfalardadır.
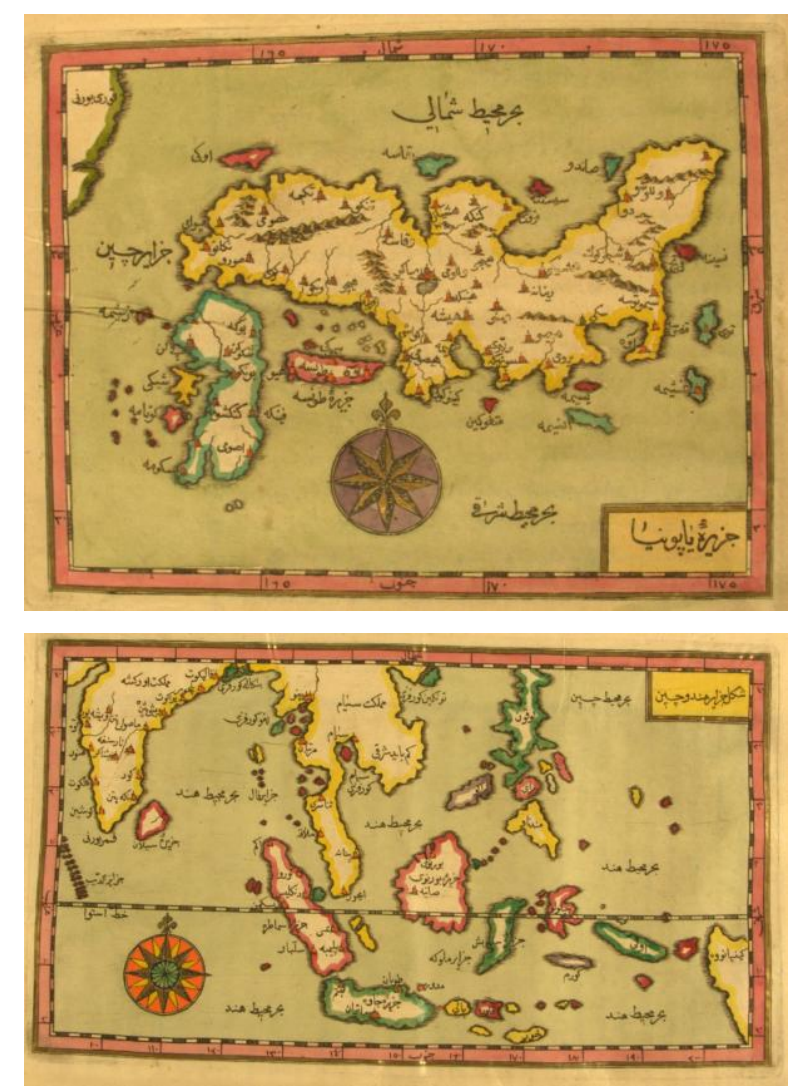

Şekil 13. Üstte Japonya (s.125-126), altta Hind ve Çin adaları (s.131-132)

Cihannüma'da yer verilen ülkelere ait bilgiler, döneminde coğrafya alanında meydana gelen gelişmelere uygun olarak ortaya çıkan yeni görüşler doğrultusunda verilmiştir. Buna göre her ülkenin bilgisi belli bir plana bağlı kalınarak tarif ve tasvir edilmiş olup konular "yönetim merkezi, yeri, coğrafi durumu, yönetim, din, ahlak, adetler, yerleşmeler, sanat, ticaret, bitkiler, hayvanlar, tarım ürünleri, madenler" şeklinde sıralanmıştır. Ayrıca ovalar, nehirler, göller hakkında da yeri geldikçe bilgi verilmektedir. Bu bilgilerin yanında, keşfedilen ülkeler ve adaların keşif tarihleri de yazılmıştır. Metin içinde ülkelere ait bilgiler, oluşturdukları gruplara göre verilerek sıralanmışlardır. Bunların her birinin son kısmında ise o sahanın ulaşım konusuyla ilgili olarak yolları ve menzilleri de anlatılmaktadır. Bu bilgiler tarihi yollar bakımından önemlidir. Eserin diğer bir özelliği de son kısımlara, anlatılan sahaya ait siyasi tarih ve siyasi coğrafya bilgilerinin konulmuş olmasıdır.

Kâtip Çelebi'nin Cihannüma adlı eserindeki ülkelere ait bilgiler bazı sahalar için uzun ve ayrıntılı, bazıları için kısa olarak verilmiştir. Bu da döneminde elde edilen bilgilerin azlığı ve çokluğu ile doğrudan ilgilidir. Eser, genel olarak verilen matematik coğrafya bilgileri, denizler ve karalar bölümü ile ülkeler bölümü şeklinde iki kısma ayrılarak değerlendirilebilir. Döneminde böyle bir eseri ortaya koymak için doğu ve batıyı çok iyi takip etmek gerekir. Kâtip Çelebi işte bunu başaranlardan biridir. 

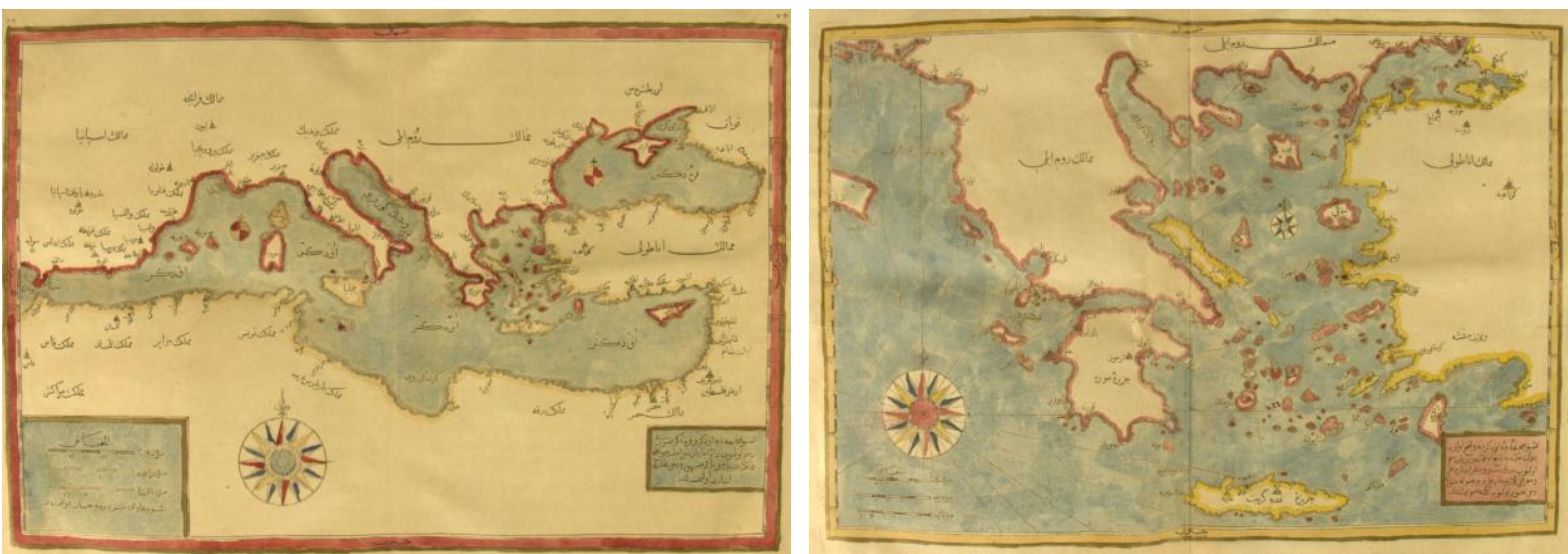

Şekil 14. Solda Akdeniz ve Karadeniz (s.75-76), sağda Ege Denizi ve Anadolu'nun batısı ile Balkan yarımadası (s. 78-78) haritaları. Bu haritalarda ölçek üç tür olarak verilmiştir. Bunlar İslam mili, Faransız mili ve İtalyan mili olarak düzenlenmiş ve hesapların beş derece için yapıldığı belirtilmiştir. Bu haritalarda birçok yeradı bulunmaktadır. Bunlardan Anadolu'da olan yeradları soldaki haritada "Antakiye, İskenderun, Anamur, Silifke, Alaiye, Atalya, Megri, Kuşadası, İzmir, Kütahya, Burusa, Ereğli, Amasra, Sinob, Giresin, Trabzon, Rize”
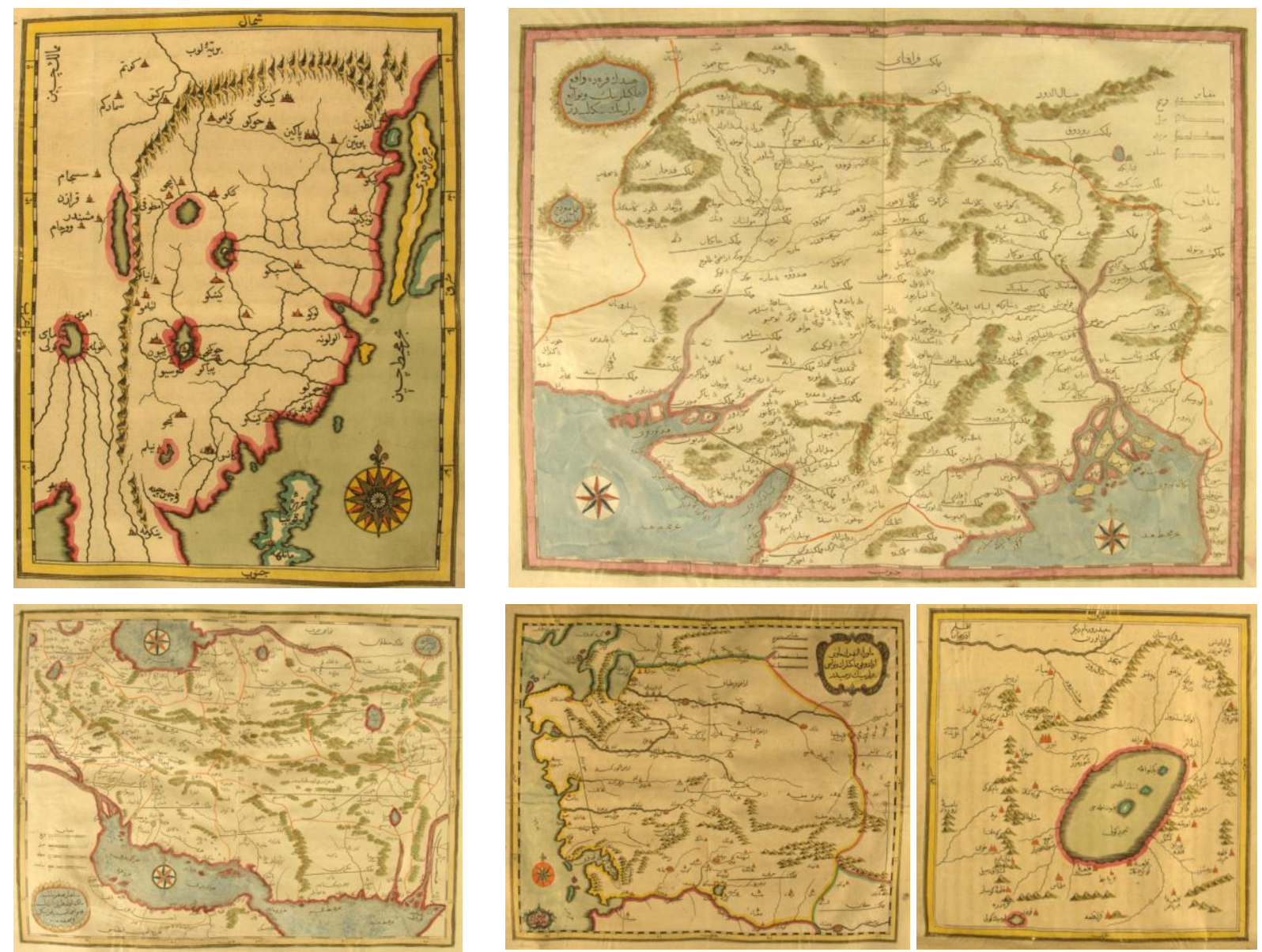

Şekil 15. Üstteki şekillerden soldaki Çin'i (s.154-155), sağdaki Hindistan'1 (s.193-194), alttakilerden soldaki İran'1 (s.291292), ortadaki Maveraünnehr'i (s.347-348) ve sağdaki Tebriz (Urmiye) Gölü’nü (s.389-390) göstermektedir. 
Kâtip Çelebi'nin Cihannüma adlı kitabına coğrafyacılar dışındaki araştırıcılar ayrı bir değer vermişlerdir. Günümüz tarihçileri kendi alanlarıyla ilgili olan birçok tarihi kaynaktan yararlandığı halde, coğrafyacılar tarihî coğrafya konularına gereği gibi eğilmemişlerdir. Bunun sonucu olarak, geçmişte yazılmış olan Cihannüma gibi önemli coğrafya eserlerinden yararlanılamamıştır. Bütün bunlara rağmen, batıda ve doğuda birçok dile çevrilmiş olan Cihannüma'dan Türk coğrafyacıların yararlanmamış olması, gelişmiş ülkelerin özellikle son zamanlarda çok önem verdiği, geçmişin coğrafyası olan "Tarihî Coğrafya" anabilim dalına ülkemiz üniversitelerinde yer verilmemesinden de kaynaklanıyor olmalıdır. Gerçekte coğrafyanın bir dalı olan Tarihi Coğrafya, nedendir anlaşılmaz, ülkemizde tarihin bir dalı olarak algılanmaktadır. Diğer taraftan, geçmişte yazılmış olan coğrafya eserleri, birçok yönden olduğu gibi aynı zamanda kültür coğrafyası bakımından da önem taşımaktadır.

Osmanlı bilim dünyası, XVI. yüzyılın sonlarına kadar yenilikleri takip etmiş, ancak devamında yeniliklerden uzak kalmıştır. Kâtip Çelebi bu durumu görüp anladığından, batıyı ve yenilikleri takip etmeye başlamıştır. Yeni gelişmeleri gördükçe, yeni eserlere baktıkça, İ̀lam dünyasındaki coğrafya eserlerini, özellikle de haritaları yetersiz bulmuş ve kendisinin kaleme aldığ ilk Cihannüma'yı yarıda bırakarak bu konuda yeni eserler verme gereğini duymuştur. Böylece Kâtip Çelebi, ikinci defa yazdığı Cihannüma'da birçok yenilik getirmiştir.

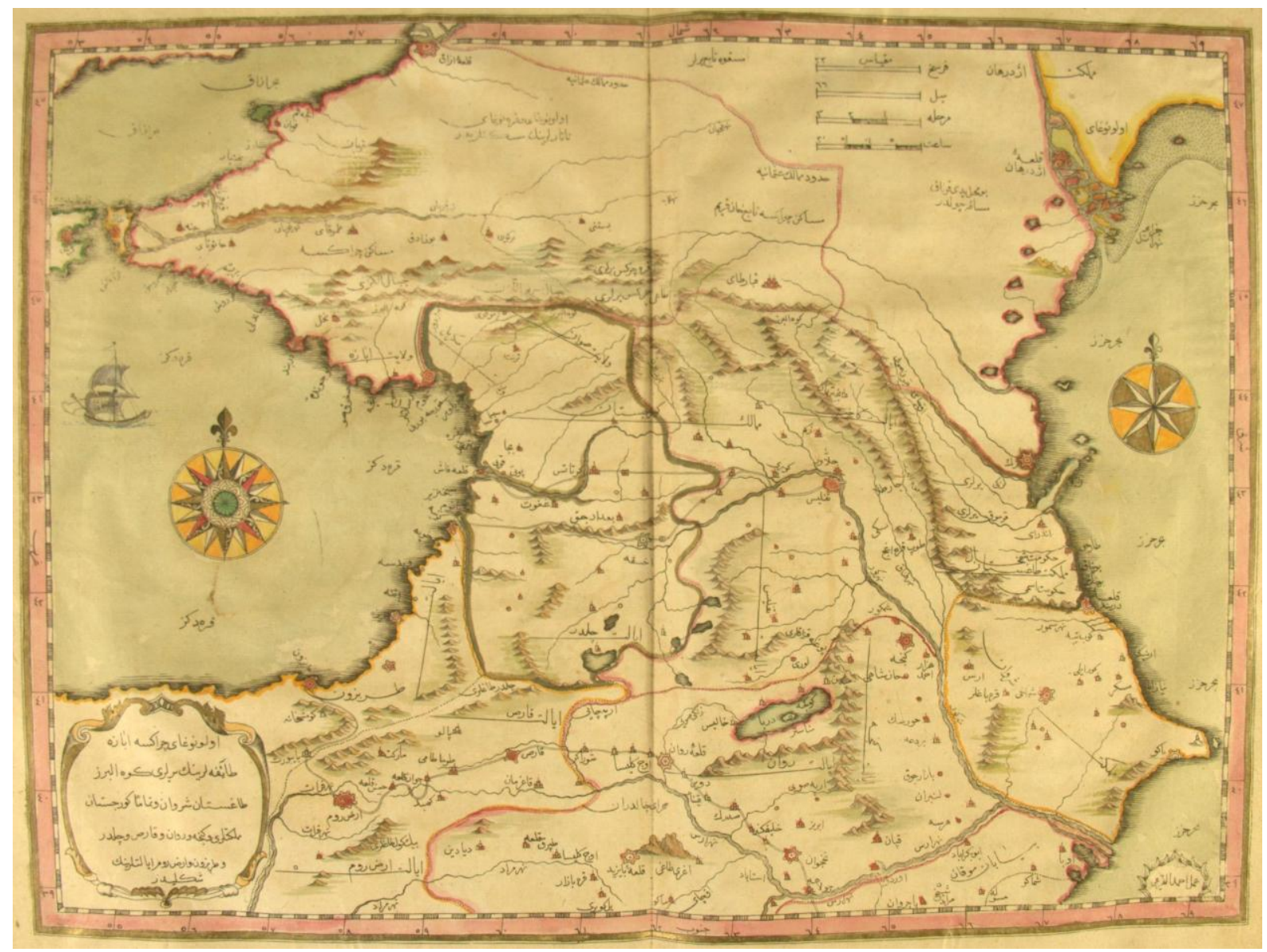

Şekil 16. Kafkas ülkeleri haritası. Haritanın sol alt köşesindeki çerçevenin içinde sahanın nereleri içine aldığı yazılmıştır. Çerçeve içindeki yerler "Ulu Nogay, Çerakese, Abaza taifelerinin yerleri, Kuh-1 Elburuz, Dağıstan, Şirvan ve tamamen Gürcistan memleketleri ve Gence ve Revan ve Kars ve Çıldır ve Trabzon ve Arz 1 Rum (Erzurum) eyaletlerinin şeklidir" diye yazılmıştır. Harita üzerindeki birçok yerin adı günümüzdeki gibidir (Kara Deniz, Gümüşhane, Bayburt, Fırat, Aras, Ağrı Dağı, Hasan Kale, Çıldır, Hopa, Kars, Kağızman, Murat vb.). Osmanlı Devleti sınırı ile eyaletlerin sınırı da çizilmiştir. Ölçek; her biri ayrı ayrı fersah, mil, merhale ve saat değerleri esas alınarak dört adet çizgi ölçek şeklinde düzenlenerek să üst kısma konulmuştur. Bu ölçeklerden 22 fersah $=66 \mathrm{mil}=3$ merhale $=20$ saat olduğu anlaşılmaktadır. Enlem ve boylam değerleri kitabede verilmiş̧ir. Haritayı yapan sağ alt köşede “Ahmed el Kırımî” olarak kaydedilmiştir. 
$\mathrm{Bu}$ yeniliklerden birincisi, sonradan yazılmış olan Cihannüma'ya konulmuş bulunan kartografya konularıdır. Buna göre Kâtip Çelebi, küre şeklinde olan dünya yüzeyini ve üzerindeki bilgileri, bir düzlem üzerine aktarmayı ve zorluklarını içine alan konuları şekiller çizerek eserine ayrıntılı olarak koymuştur. Özellikle bu eserde, yeryüzündeki bir noktanın tarifi için gerekli olan enlem, boylam, paralel ve meridyen terimleri üzerinde durulmuştur. Ayrica, bu bilgilerin haritacıllk bakımından önemi de vurgulanmıştır.

Büyük coğrafi keşiflerin sonucunda dünyaya ait bilgilerin çoğalması, batıda haritacılığın gelişmesini sağlamış, bundan Osmanlı haritacılığı da önceleri olumlu yönde etkilemiştir. Piri Reis gibi Osmanlı denizcileri, "portolan" adı verilen, özellikle deniz yollarını gösteren haritalar yapmışlar ve "Kitab-1 Bahriye" gibi denizcilikte önemli olan kılavuz niteliğindeki eserleri yazmışlardır.

Evliya Çelebi gibi seyyahlar ile diğer yazarlar da seyahatname ve menzilname gibi eserler vermişler ve yol haritaları yapmışlardır. Kâtip Çelebi'nin önemli yanlarından biri de döneminde ortaya çıkan yeni gelişmelere bakarak, coğrafyanın ve coğrafi eserlerin haritasız olamayacağını kavramış olmasıdır. Bu sebeple yeni yazdığı Cihannüma’ya birçok şekil ve harita eklemek istemiş, fakat istediği kadar şekil ve haritayı eserine koyamamıştır. Ancak yüz yıl sonra İbrahim Müteferrika, Cihannüma’ya birçok şekil ve harita ekleyip basarak, bir ölçüde Kâtip Çelebi’nin arzusunu yerine getirmiştir.

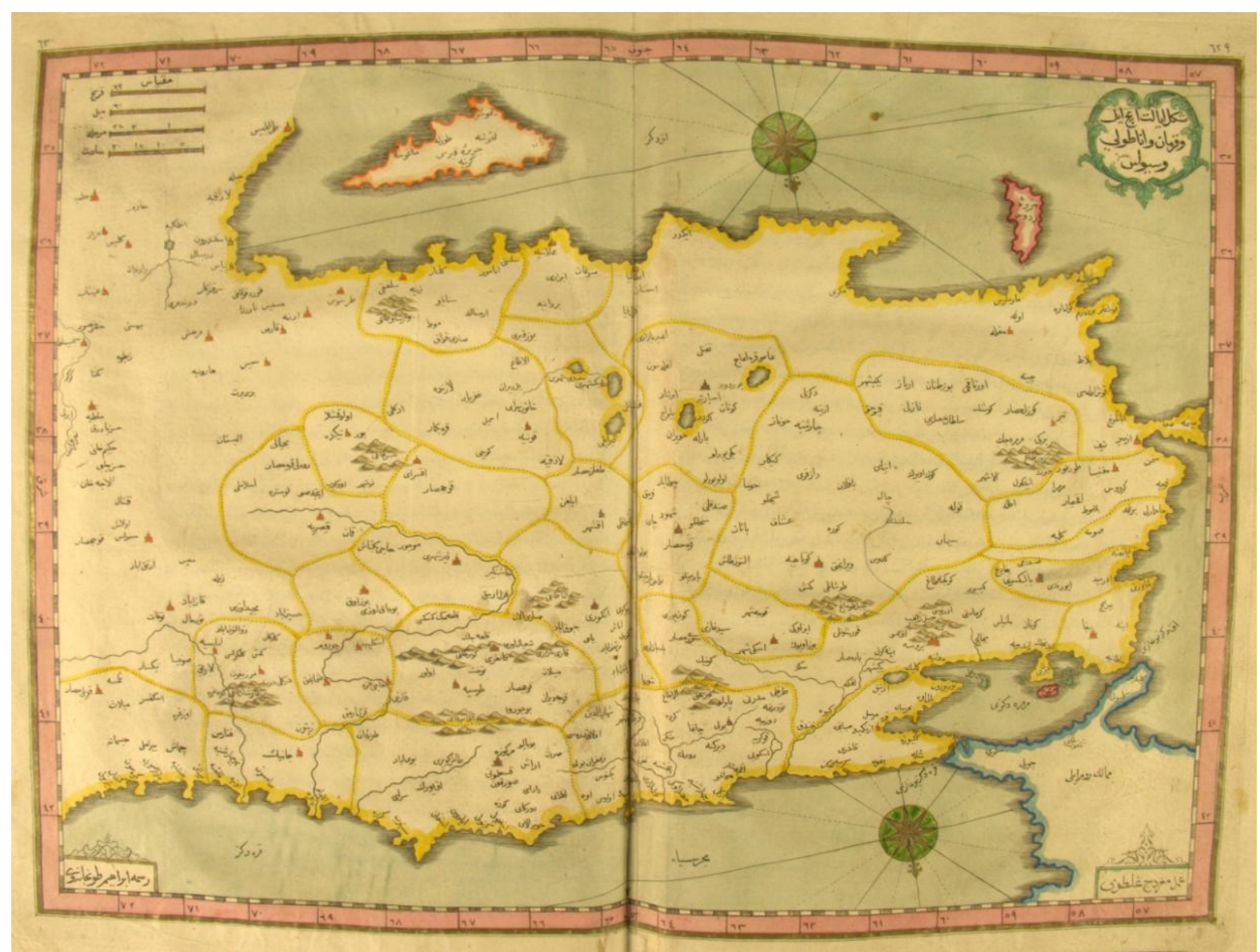

Şekil 17. Harita diğerlerinden farklı olarak İdrisi’nin haritasındaki gibi güneyi üstte, kuzeyi altta, doğusu solda, batısı sağda olacak şekilde yapılmıştır. Yönler kitabeye konulduğu gibi şeklin alt ve üst kısmına konulmuş olan rüzgârgüllerinden de anlaşılmaktadır. Haritanın başlığı sağ üst köşede "Şekl-i Eyalet-i İçil ve Karaman ve Anadolu ve Sivas" olarak yazılmıştır. Ölçek ayrı ayrı çizgi ölçek şeklinde "Fersah, Mil, Merhale, Saat" esasına göre düzenlenerek şeklin sol üst köşesine konulmuştur. Harita üzerinde Anadolu'daki yönetim birimlerinin sınırları ve birçok yeradı mevcuttur. Döneminde kullanılan enlem ve boylam değerleri kitabede verilmiştir. Haritayı yapan, şeklin sağ alt köşesine "Mıgırdıc Galatavi” olarak yazılmıştır (s.629-630). 
Kâtip Çelebi, bütün bunların yanında ülkeleri gezmenin de coğrafya bakımından önemli olduğunu anlamış, özellikle Osmanlı toprakları ile yakın çevrelerini gezip görmüştür. Gezdiği alanları kendisi “Anadolu'nun tamamı, Azerbaycan, Şam (Suriye), Irak ve Hicaz" olarak sıralamaktadır. Söz konusu ülkeleri gezip gördükçe, daha önce yazılmış eserlerdeki birçok bilginin noksan hatta yanlış olduğunu da anlamış ve bunu eserinde belirtmiş̧ir. Ayrıca yazar, karaların coğrafyasını yazmanın denizlerin coğrafyasını yazmadan daha zor ve zahmetli olduğunu da eserinde vurgulamaktadır.

Daha önce yazılmış olan İslamî eserler ile Kâtip Çelebi'nin yazdığı birinci Cihannüma'da dünya üzerindeki ülkeler genel olarak yedi iklime ayrılarak verilmiştir. Oysa ikinci defa yazılan Cihannüma'da ülkeler Asya, Avrupa, Afrika, Amerika kıtalarına göre anlatılmış ve ayrıca Kuzey Kutbu, Güney Kutbu konularına da yer verilmiştir. Kıtalara ayırma yöntemi ilk defa kullanılmıştır. Bu da döneminin önemli coğrafi yeniliklerinden biridir.

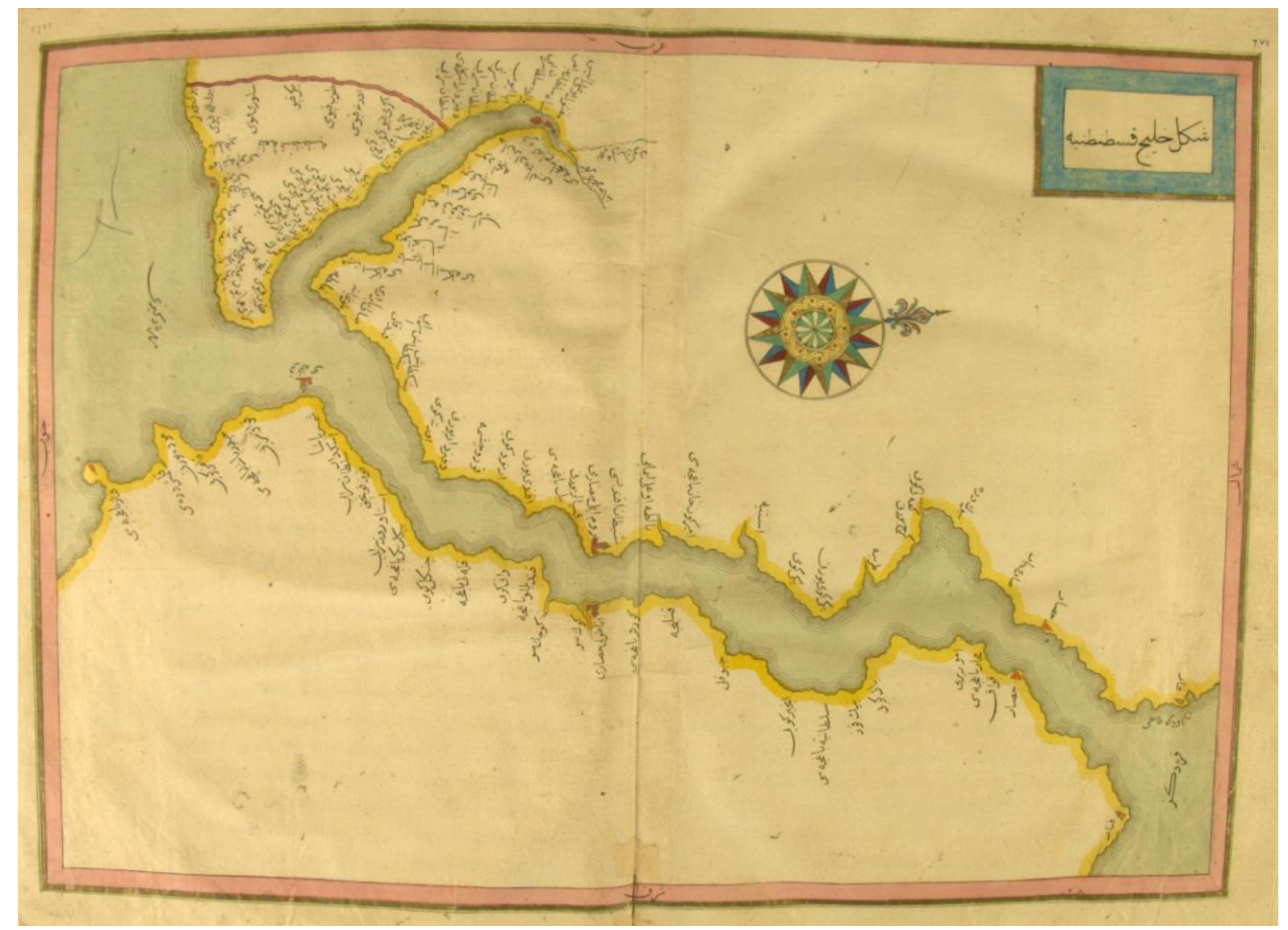

Şekil 18. İstanbul, İstanbul Boğazı ve Haliç haritası. Haritanın kuzeyi rüzgargülüne göre sağ taraftadır. Başlık sağ üst köşeye "Şekl-i Haliç Kostantinye" olarak yazılmıştır. Haliç ile Marmara Denizi arasında yer alan İstanbul, Haliç ve İstanbul Boğazı kıyısında döneminde var olan yerleşmeler bu harita üzerine yazılmıştır. Yönler kitabede verildiği gibi şeklin orta kısmına konulmuş olan rüzgargülünden de anlaşılmaktadır (s.671-672).

Kâtip Çelebi'nin Cihannüma'sından önce yazılan coğrafya eserlerinde, sadece tasvire yer verilmiş olup, genel ve matematik coğrafya ile bölgesel veya ülkeler coğrafyası arasında senteze dayalı bir bağ olmadığı görülmektedir. Oysa Cihannüma'da, bunların arasındaki ilgiler sentez olarak kurularak birlikte kullanılmış ve bunlara bir de tarihî coğrafya bilgileri eklenmiştir. Ayrıca, ülkelerle ilgili konuların son kısmına o sahanın genel tarih bilgileri de konulmuştur. 


\section{Sonuç}

Kâtip Çelebi'nin Cihannüma ile döneminde coğrafya alanına getirmiş olduğu yenilikleri şu şekilde siralamak mümkündür.

1- Daha önce yazılmış olan diğer eserlerden yararlanma.

2- Matematik Coğrafya ve Kartografya konularına yer verme.

3- Esere konularla ilgili şekiller ve haritalar koyma.

4- Dünyayı kıtalara ayırarak, buna göre ülkeleri anlatma.

5- Ülkeleri anlatırken konulara uygun belli bir sıra izleme.

6- Anlatılacak sahaları coğrafyacının gezip görmesi.

Kâtip Çelebi’nin ikinci defa yazdığı Cihannüma adlı eserinde kullandığı bu yenilikler, döneminde hiç şüphesiz coğrafya alanında çığır açmıştır. Günümüzde de coğrafya alanında yapılan araştırmalar genel hatlarıyla bu niteliklere sahiptir.

Hayatının kısa sürmesine karşılık Kâtip Çelebi (Şubat 1609 - 6 Ekim 1657), yalnız coğrafya alanında değil daha birçok sahada değerli eserler vererek, XVII. yüzyıla önemli bir bilim insanı ve araştırıcı olarak damgasını vurmuştur. Ortaya koyduğu tüm eserleri Katip Çelebi'yi evrenselleştirmiştir. Eserlerinin her biri günümüzde de birçok ülkede araştırmacılar tarafindan kullanılmaktadır. Coğrafya ve özellikle tarihi coğrafya bakımından, önemli bir kaynak olan Cihannüma ise değerini hiç kaybetmeyecek, coğrafyacılar ve diğer araştırıcılar bu eseri her kullandığında veya ondan yararlandığında Kâtip Çelebi'yi de hep övgüyle anacaklardır.

\section{Referanslar}

Ağarı, M. (2002) İslam Coğrafyacılı̆̆ ve Müslüman Coğrafyacılar, Kitabevi Yay. ISBN 975-7321-63-X. İstanbul. Akyol, İ. H. (1940) Tanzimat Devrinde Bizde Coğrafya, Maarif Matbaası, İstanbul. Gökyay, O. Ş. (1977) "Kâtip Çelebi”, İslam Ansiklopedisi, 6. cilt. s.432-438, İstanbul.

Gökyay, O. Ş. (1982) Kâtip Çelebi, İkinci baskı, İş Bankası Genel Yay. No: 232, Edebiyat dizisi 57, Ankara.

Gökyay, O. Ş. (1991) “Kâtip Çelebi; Hayatı, Şahsiyeti, Eserleri”, Türk Tarih Kurumu Yay. VII. Dizi, 33b: 3-92, Ankara.

Oruç, Ş. - Tokcan, H. - Demirkaya, H. (2006) “Osmanlı Dönemi Coğrafya ve Coğrafya Öğretimi”, Beyazkalem Yayıncılık, Ankara.

Pitcher, D.E. (1972) “An Historical Geography of the Ottomam Empire”, Leiden.

Ramsay W. M. (1961) “Anadolu'nun Tarihi Coğrafyası (Çev. Mihri Pektaş), MEB, İstanbul.

Selen, H. S. (1991) “Cihannüma. Kâtip Çelebi. Hayatı ve Eserleri Hakkında İncelemeler”, Türk Tarih Kurumu Yay. VII. Dizi, 33b: 121-136, Ankara.

Taeschner, F. (1924) “Das Anatolische Wegenetz nach Osmanischen Quellen (2 vols)”, Leipzig.

Türkay, C. (1999) "Osmanlı Türklerinde Coğrafya”, MEB Yay., İstanbul.

Unat, Y. (2002) "Osmanlılarda Coğrafya", Bilim ve Ütopya, 95: 31-331.

Yaman, T. M. (1940) “Cihannüma’nın İlaveli Bir Nüshası”, Ülkü Mecmuası, 85, 86, 87'den ayrı basım. 
